\title{
RESEARCH OF COMPETITION IN DEPOSIT MARKET OF UKRAINE BASED ON THE PANZAR-ROSSE MODEL
}

\author{
Iryna DIDENKO', Serhii BOHMA \\ Ukrainian Academy of Banking, Ukraine
}

\begin{abstract}
The problem in an adequate assessment of the level of competition in the banking market has prompted researchers to search constantly some new methods. The most famous of them were later successfully adapted to the banking market, are a models of Bresnahan, Panzar-Rosse, Bertrand, Iwat, Monti-Klein-Modesto Barros and others. In Ukraine, the process of assessing the level of competition in the banking sector is very relevant, in line with the recent reforms of particular relevance and distribution. Regarding the domestic deposit market, there is a shortage of qualitative analysis of this issue, unlike foreign practice. Therefore this study we try to solve this problem. The key goal of researchers in this study is in a detailed analysis to identify the important factors which make influence on the allocated markets, in particular on lending and deposit rates. Based on these factors there could be implemented internal adjustment processes taking place in the markets. The purpose of the article is to determine the level of competition in the deposit market of Ukraine in 2006-2015 basing on nonstructural PanzarRosse model and identify key factors that affect this level. Methodology. To research the level of competition in the deposit market of Ukraine the Panzar-Rosse model was used, in which separate 11 models were built using the integrated tool "Multiple regression" in the software package of statistics analysis STATISTICA. The input data in the model was presented with the information on financial performance of Ukrainian banks during ten years from 01.01.2005 till 01.01.2015. Results of this research showed that in Ukrainian deposit market there is a monopolistic competition, as proved by the calculated values of $\mathrm{H}$-statistics index. The year of 2008 , in the context of the global economic crisis, was marked as an unbalanced period for deposit market of Ukraine. Practical implications. Knowing the current state of competition level in the market, a number of phenomena that occur in it can be explained and a number of effective measures for its control can be designed. Value/originality. In Ukraine, the process of assessing competition in the banking sector, in line with the recent reforms, is becoming more popular and relevant. As for the domestic deposit market, there is a shortage of qualitative analysis of this issue, unlike the foreign practice. So this research will help to solve the problem.
\end{abstract}

Key words: banking system, competition, deposit market, Panzar-Rosse model, H-Staistics Index.

JEL Classification: C30, G10, G21

\section{Introduction}

In terms of the selected by Ukraine vector of European integration and in the context of globalization processes taking place in the modern world economy, the requirements to domestic business are becoming tougher and higher. Now in the forefront there are not the quantitative indicators of economic subjects, but the quality of the products and services provided by them in the market. Therefore the struggle in all economic sectors becomes more aggravated and the banking system is not an exception. The deposit market as an integral part of the banking sector is also a subject to competitive processes both from the side of the banks and of the clients. The conjuncture of any market means not just the interaction between supply and demand on it, but also the level of competition, which is a key factor in establishing the equilibrium price in the market. As for the deposit market - it is the equilibrium deposit interest rate. Besides, knowing the current competitive situation in the market, we can introduce the use of certain regulatory measures from external or internal regulator.

The problem of adequate assessment of the competition level in the market of banking services incited researchers to continually look for new approaches to do this. The most famous of them, which were successfully adapted later to the banking market, are the models of Bresnahan, PanzarRosse, Iwata, Bertrand, Monti-Klein, Barros-Modesto and others. In Ukraine the process of assessing the level of competition in the banking sector, in line with the recent

\footnotetext{
Corresponding author:

${ }^{1}$ Department of Banking, Ukrainian Academy of Banking.

E-mail: Iryna.Dydenko@mail.ru

2 Department of Banking, Ukrainian Academy of Banking.

E-mail: s.d.bogma@gmail.com
} 
reforms, becomes topical and spreading. Concerning the domestic deposit market, there is some shortage of qualitative analysis of this issue, unlike the foreign practice. So this research is aimed at solving this problem.

\section{Literature review}

The competition is an integral part of market relations. A set of important points such as existing market risks, presence / absence of barriers for new institutions to entry the market, establishing the equilibrium market price, policy measures of market regulator, presence of systemically important institutions, market concentration et al. depends on the type of competition in the market (monopoly, oligopoly, monopolistic or perfect). That's why, from the half of XX century various researchers were interested in the question whether it is needed to know the level of competition in a particular market, how it can be measured and if the relationship between competition and other components of the market can be traced.

Thus, Xavier Vives (Xavier, 2001) investigates the main trends of interdependence between the level of competition and regulation of the banking system, the banking market concentration degree and type of competition on it. Basing on the results of analysis, Xavier Vives states that the current market of banking services is too diverse that it needs to be researched individually for every segment. Accordingly the optimal level of competition will depend on institutional characteristics of the market and other internal and external factors. For each country there is its own optimal level of competition: for developed countries with a high level of information publicity and low social costs a high level of competition is common, and for developing countries and countries with low economic level competition is insignificant.

The problem of qualitative aspects of competition among banks was also studied by Nicola Cetorelli (Cetorelli, 2001). He considered the approaches of different authors on the positive and negative qualities of different types of competition in the banking environment. The key thesis of this study was that in any case, whether it is monopoly or perfect banking competition, it will have the same positive and negative effects on aspects of banking activity. Therefore the ideal situation is to look for a certain compromise between market participants which would set the optimal level of competitive environment. Nicola Cetorelli also notes that while regulating the situation in the banking sector the impact of institutions from other sectors of the economy must be considered.

Besides mentioned authors the problem of competition in the banking sector was researched by other researchers: O. Y. Hirna (Hirna, 2014), S. V. Leonov (Leonov, 2009), S. Drobyshevskyi (Drobyshevskyi, 2006), M. E. Mamonov (Mamonov, 2010), J. Barth (Barth, 2000), S. Shaffer (Shaffer, 1998) and others.

Having defined the fact that detecting and calculating the level of competition is important, approaches and methods of its assessment began to appear. Totally there are two big groups of approaches to assess the level of competition: structural and non-structural (Moiseev, 2007). Structural approaches are based mainly on the assumption that market competition is influenced by its structure, i.e. a set of indicators that includes a number of subjects of particular industry, size of firm, the level of product differentiation and size of barriers to market entry (Goddard et al., 2001). Within the structural approach two key hypotheses are standing. The first hypothesis "Structure-Conduct-Result" (SCR) or as it is called Harvard paradigm was proposed in 50s of XX century (Bain, 1951) implies dependence of competition level in the market on the share of a particular market sector, number of market participants (concentration). Therefore, to assess competition within the first hypothesis concentration coefficients (Herfindahl-Hirschman Index), entropy indexes and Ginny coefficients are used. In twenty years later within the structural approach another important hypothesis was put forward - "Efficient Structure" (ES) (Demsetz, 1973). The content of the second hypothesis is different from the previous one and brings on the first place the effectiveness of the activities of market participant. The more effective are participants, the higher the level of their concentration, and therefore profit and prices. When using structural approaches to assess competition level several disadvantages were found. One of them is that structural methods don't allow detecting influence of hidden factors. In addition, high concentration level cannot guarantee the availability of market power. In this regard, in the 80 s non-structural methods of assessing the level of market competition appeared. They allowed assessing the level of competition in the market basing on the behavior of market participant and a number of other factors. The main non-structural models include models of Barros-Modesto (Barros, 1999), Bresnahan (Bresnahan, 1982), Iwata (Iwata, 1974), Lau (Lau, 1982), PanzarRosse (Panzar and Rosse, 1987) and others.

\section{Overview of Ukraine's banking system and its deposit market}

The banking system of Ukraine in modern conditions of development is going through a very complex and unstable period. Structural economic changes that had been taken place after crisis years of 2008-2009, and the political crisis in Ukraine, which had begun in the end of 2013 and continues to this day originated the beginning of the "reset" phase of banking. According to the Strategy of sustainable development "Ukraine-2020" within the signed international legal acts, in particular about Association Agreement between Ukraine and the EU (Agreement, 2015) and the Memorandum of Cooperation with the International Monetary Fund (Memorandum, 2015), financial sector general reformation is conducting, within which the processes of transformation of the banking system are also taking 
place as well. More detailed information about the major reforms which are carried out in the banking system of Ukraine can be found on the official website of National Council of Reforms (Reforms). The current Head of the National Bank of Ukraine (NBU) Valeriya Gontareva during the last meeting of the Finance Committee of the Verkhovna Rada in April 2015 (Verkhovna Rada, 2015) noted that the banking system of Ukraine is going through three key stages of reformation: cleaning, rebooting and ensuring sustainable development of the banking system. Thus, she noted that cleaning of domestic banking system had been successfully finished and ended in June 2015. The main results of this stage are: extra capitalization of 35 largest banks that have successfully passed the stress tests in 2014 and reduction in the total number of banks at the expense of the third and fourth groups. As of the end of 2015 the number of banks with banking license was 120, that is 43 less than at the beginning of the year. Such policy of the NBU was a result of banking sector general assessment, where 85 $\%$ of main banking operations are provided by the first 35 banks. In addition, the Committee on supervision and regulation of banks ' activity, supervision of payment systems the NBU published information about that three banks at the moment to date are systemically important (PJSC "Privatbank", PJSC "Oschadbank" and JSC "Ukreximbank"), which creates a reason to keep attentive oversight of their activities (NBU).

According to the next stage of reformation of the banking system of Ukraine, that is "reboot", V. Gontareva notes that it needs time for implementation, in particular, for the gradual liberalization of restrictions on the foreign exchange market and the market of retail deposits, strengthening the role of corporate governance in Ukrainian banks and risk management to attract depositors ' confidence.
The third stage of establishing sustainable development of the banking system is scheduled for the last years of the Strategy "Ukraine-2020". A key thesis on this stage is to achieve an inflation level at $5 \%$ and provide country`s economy with available resources for further economic growth.

In addition to mentioned facts, we can point out the following main statistical changes in the banking system of Ukraine during the last year (according to the National rating agency "Rurik" (Rurik, 2015):

- reducing the NBU discount rate from $30 \%$ to $22 \%$;

- during 9 months of 2015 the net assets of banks in Ukraine reduced by $8,2 \%$ and as of 01.10 .2015 were 1208,88 billion grn., which was caused by a reduction of the general number of banks and outflow of depositors' money because of mass panic among population (provoked by the loss of confidence in the banking system and the devaluation of the national currency (UAH)). At this time, there was a slight increase of foreign currency assets - since the beginning of the year till October 2015 the share of foreign currency assets increased from $43,7 \%$ to $47,71 \%$;

- the amount of the loan portfolio also decreased by $9,47 \%$ and as of 01.10 .2015 was 911,02 billion grn., while the biggest part in it (55\%) was occupied by foreign currency loans;

- for the first 9 months of activity of the banking system of Ukraine in 2015 it received a negative financial result net loss of 51530 million grn. This situation is explained by reduction of asset quality of banks and the lack of reserves of the banking system.

Concerning the deposit sector of the domestic banking system, there is a tendency of reducing the number of long-term deposits, meanwhile the average interest rate on deposits in the national currency as of 01.10.2015

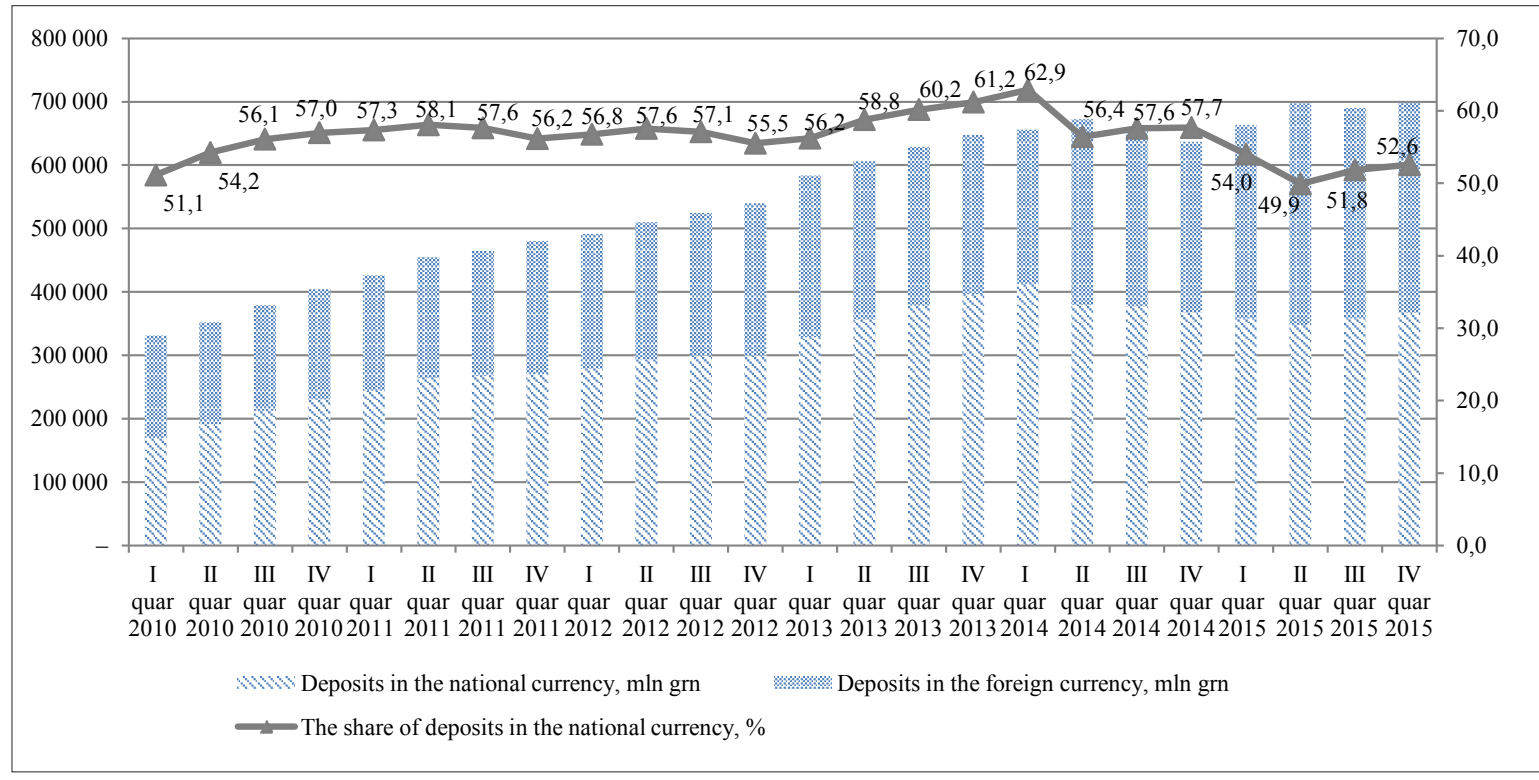

Fig. 1. Dynamics of deposits in national and foreign currencies in 2010-2015 
relatively to beginning of the year increased from $12,8 \%$ to $15,2 \%$, and in foreign currency decreased from $8,6 \%$ to $7,3 \%$. General picture of deposits in national and foreign currencies is as follows (Fig. 1).

As we can see the share of deposits in the national currency is bigger than the half of all deposits of clients during 2010-2015. The only exception is the second quarter of 2015, when the share of deposits in national currency decreased from $54 \%$ to $49,9 \%$, that can be explained by the devaluation of the hryvnia against foreign currencies (including the dollar and euro) and the unstable economic situation in the country. Generally within 5 years there is a positive dynamics of total amount of deposits. As for the concentration of attracted funds, according to the analytical resource Bankografo (Bankografo) the distribution of deposits between acting banks as of 01.10.2015 is following: "Privatbank" - 34,3\%, "Oschadbank" - 12,0\%, "Ukreximbank" - 6,3\%, "Raiffeisen Bank Aval" - 4,2\%, "FUIB" $-3,5 \%$. So we can see that over $60 \%$ of all attracted funds are concentrated in 5 largest banks of Ukraine which allows assuming that Ukrainian deposit market is highly concentrated. The main problem here may be the fact that according to the latest news published on the website of the NBU regarding systemically important banks, 3 of 5, namely "Privatbank", "Oschadbank" and "Ukreximbank" are systemically important for the whole economy. This, in turn, endangers safety of deposit market.

\section{The model of Panzar-Rosse}

The Panzar-Rosse model was first proposed over the public in 1987 by two American scientists J. Panzar and J. Rosse (Panzar and Rosse, 1987), in whose honor this model was named. Also, often referring to this model, the term "H-statistics" is used. This is the indicator that is calculated to assess the level of competition.

From the beginning, this model was used to assess the level of competition in the real sector of the economy, and only later gained popularity in the banking sector. Today the model of Panzar-Rosse has gained popularity and is used to assess the level of competition in the banking system in many countries: the USA, Latin America, the European Union, Southeast Europe, Africa (Kenya, Nigeria, South Africa, Uganda, Tanzania, Zambia, etc.), India, Persian Gulf countries, Turkey and others (Moiseev, 2007).

This model has gained such popularity in the world by some of its advantages over other non-structural models: - is a universal tool for assessing the level of competition in different countries (with different levels of economic development), that allows comparing results between each other and make inter-regional analysis;

- allows evaluating the level of competition as both on a separate segment and the whole market in general;

- aimed at maximizing profits in a competitive environment;

- when using this model usually there is no problem with incoming information that is publicly presented.
One more important feature of the Panzar-Rosse model is that it considers banking system in a state of long equilibrium, that is why calculated index of $\mathrm{H}$-statistics is considered reliable including this condition. The general empirical form (specification) of Panzar-Rosse model for assessing the level of competition of the whole banking system is as follows (Bikker et al., 2007):

$\ln (P R)=\alpha_{0}+\alpha_{1} \cdot \ln (F I P)+\alpha_{2} \cdot \ln (B S F)+\alpha_{3} \cdot \ln (T A)+\varepsilon,(1)$

where $\alpha_{0}$ - constant, free term in a model;

$a_{1}, a_{2}, a_{3}-$ model coefficients;

$P R$ - interest income of the bank;

FIP - variable, which reflects the prices on factors of production;

$B S F$ - variable, which describes the specific bank factors;

TA - total assets;

$\mathcal{E}$ - the value of random error.

The value of H-statistics index is defined as the sum of coefficients in the model for the first two variables FIP and BSF:

$$
\text { Hstat }=\alpha_{1}+\alpha_{2}
$$

The interpretation of the values of $\mathrm{H}$-statistics can be done in the following way:

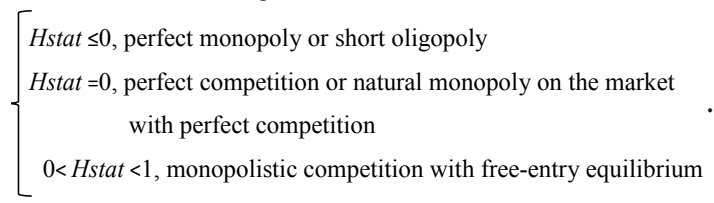

But the condition (3) should also be a little supplemented since using $\mathrm{H}$-statistics index we can also determine the degree of equilibrium in the market. If this figure is not equal to and bigger than 0 , then we can assume that there is a market equilibrium, if it is equal to and less than 0 , then accordingly the market is unbalanced.

\section{Results}

During the studying the level of competition in the deposit market of Ukraine we used the specification of Panzar-Rosse model as stated above (1). However, we have changed the composition variables, focusing on those which, in our opinion, define the level of competition in the deposit market. As a result we got the following view of the Panzar-Rosse model for the deposit market of Ukraine:

$$
\begin{aligned}
& \ln (P R)=\alpha_{0}+\alpha_{1} \cdot \ln (\text { Liq })+\alpha_{2} \cdot \ln (\text { Effic })+ \\
& +\alpha_{3} \cdot \ln (\operatorname{Re} s)+\alpha_{4} \cdot \ln (B S F)+\varepsilon,
\end{aligned}
$$

where $a_{0}$ - constant, free term in a model;

$a_{1}, a_{2}, a_{3}, a_{4},-$ model coefficients;

$P R$ - interest income of the bank;

Liq - variable that characterizes the bank's liquidity (the ratio of bank assets to bank liabilities, \%);

Effic - variable that describes the effectiveness of passive operations of the bank (the ratio of interest costs of the bank to attracted funds);

Res - variable that describes ratio of the share of reserves for debt on bank loans to its total assets; 
$B S F$ - variable that describes specific bank factors;

$\mathcal{E}$ - the value of random error.

Thus, in the formula (4) we are dealing with an aggregate variable BSF, which reflects specific bank factors that we believe are essential in assessing the level of competition in the deposit market. These indicators include: the ratio of the bank's equity, customer deposits, unpaid assets, administrative expenses to its total assets and ratio of paid bank assets to its paid liabilities.

From our point of view, basing on the presented model (4), we assume that the level of competition in the deposit market of Ukraine, that is H-statistics index, is calculated as the sum of found coefficients of the model $a_{1}, a_{2}, a_{3}(5)$ :

$$
\text { Hstat }=\alpha_{1}+\alpha_{2}+\alpha_{3}
$$

As input data for our model we used information on financial results of banks in Ukraine in the period of 01.01.2005-01.01.2015 (NBU). We found the logarithm of left and right sides of the equation (4), built 11 models using the integrated tool "Multiple regression" in the software package of statistics analysis STATISTICA. The values of coefficients are statistically significant, and the

Table 1

Calculated values of $\mathbf{H}$-statistics index for the deposit market of Ukraine over the period of 01.01.2005-01.01.2015.

\begin{tabular}{|c|c|c|}
\hline № & Year & Hstat \\
\hline 1 & 01.01 .2005 & 0,229 \\
\hline 2 & 01.01 .2006 & 0,127 \\
\hline 3 & 01.01 .2007 & 0,128 \\
\hline 4 & 01.01 .2008 & 0,057 \\
\hline 5 & 01.01 .2009 & $-0,549$ \\
\hline 6 & 01.01 .2010 & 0,396 \\
\hline 7 & 01.01 .2011 & 0,289 \\
\hline 8 & 01.01 .2012 & 0,41 \\
\hline 9 & 01.01 .2013 & 0,363 \\
\hline 10 & 01.01 .2014 & 0,432 \\
\hline 11 & 01.01 .2015 & 0,186 \\
\hline
\end{tabular}

coefficient of determination R2 for all models is bigger than 0,5 , that indicates the adequacy of the results.

The values of calculated $\mathrm{H}$-statistics index for the deposit market of Ukraine over the period are presented in Table 1.

As we can see from the results, during the period in deposit market of Ukraine, as in the banking system as a whole, there is monopolistic competition. By the way, this trend is inherent in the European Union. We should pay attention on the values of $H$-statistics index as of 01.01.2009, which is less than $0-$ Hstat $=-0,549$. This shows not just the presence of perfect monopoly on the market, but also the conjuncture changes in the structure of the market, which led to its imbalance. In fact the same situation is observed during crisis events in 2008-2009, that left its negative effects on the domestic banking sector.

Let's follow the correlation between $\mathrm{H}$-statistics index and the number of banks that were carrying out its activities during the analyzed period (Fig. 2).

Basing on the presented Figure 2 we can say that the crisis years of 2008 and 2009 were characterized by significant increase in the total number of banks presented in the market. The maximum number of them actually in 2008 and 2009 is characterized by low level of competition in the system. The situation in Ukraine's banking sector and in the economy as a whole (as of 01.01.2009) was generally unbalanced, that proves the sharp fall in values of $\mathrm{H}$-statistics index.

\section{Conclusions}

1. Since the middle of XX century the question of assessing competition was under active discussion by scientists. In this case, the main assessment methods were combined into two groups: structural and non-structural. After series of studies of different scientists strengths and weaknesses of both approaches have been identified. However, modern scientists give priority to nonstructural approach that leads to an active development

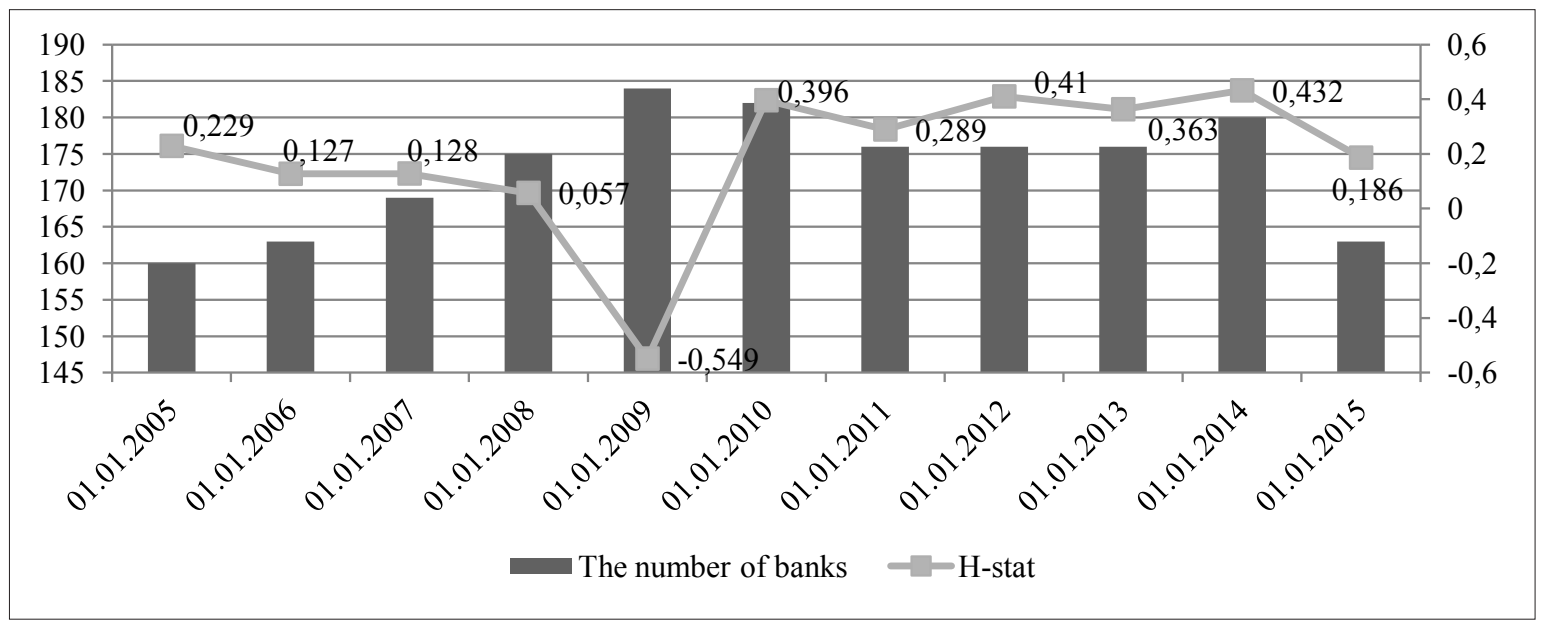

Fig. 2. Dynamics of the level of competition (H-statistics index) in deposit market of Ukraine regarding to the total number of banks during 2005-2015 
of appropriate models. The Panzar-Rosse model is one of these models, which today is a leading one in assessing the level of competition in different countries. Therefore, we chose this model in our study.

2. An active process of reforming all sectors of Ukraine is clearly described in the financial sector too, including the deposit market. Therefore, the relevance of assessing the level of competition is of particular importance for its further regulation.
3. As a result we found that the deposit market of Ukraine is inherent in monopolistic competition, as evidenced by the calculated values of the $\mathrm{H}$-statistics index. In 2008, in the context of the global economic crisis, there was present an unbalanced situation in the deposit market of Ukraine. There is no clear link between the number of banks and the level of competition. But this research should be continued, since today the number of domestic banks is declining, that by all means imposes the level of competition in the market.

\section{References}

Uhoda pro Asotsiatsiiu mizh Ukrainoiu, z odniiei storony, ta Yevropeiskym Soiuzom, Yevropeiskym spivtovarystvom $\mathrm{z}$ atomnoi enerhii i ihnimy derzhavamy-chlenamy, $\mathrm{z}$ inshoi storony (2015) [Electronic resource]. - Retrieved from: http://zakon4.rada.gov.ua/laws/show/984_011/page.

Memorandum of Economic and Financial Policies (2015) [Electronic resource]. - Retrieved from: http://www.imf.org/External/NP/LOI/2015/UKR/072115.pdf.

Zasidannia profilnoho finansovoho komitetu Verkhovnoi Rady Ukrainy (2015) [Electronic resource]. - Retrieved from: http://interfax.com.ua/.

Natsionalnyi Bank vyznachyv try systemno vaglyvyh banky [Electronic resource]. - Retrieved from: http://www.bank.gov.ua/control/uk/publish/article?art_id=27652722\&cat_id=55838.

Analitychnyi ohliad bankivskoi systemy Ukrainy za 9 misiztsiv 2015 r. (Rating Agency "Rurik") [Electronic resource]. - Retrieved from: http://www.rurik.com.ua/documents/research/bank_system_3_kv_2015.pdf

Deposyty, zalycheni deposytnymy korporatsiizmy (krim Natsionalnoho banku Ukrainy). [Electronic resource]. Retrieved from: http://www.bank.gov.ua/control/uk/publish/article?art_id=24338412\&cat_id=12063884.

Analitychnyi ohliad bankiv Ukrainy, deposyty (Bankografo) [Electronic resource]. - Retrieved from: http://bankografo.com/analiz-bankiv/bankivska-analityka.

Vives, X. (2001). Competition in the changing world of banking. Oxford review of economic policy, 17(4): $535-547$. Cetorelli, N. (2001). Competition among bank: Good or bad? Federal Reserve Bank of Chicago. Economic Perspectives, 20: 38-48.

Drobyshevskyi, S. \& Pashchenko, S. (2006). Analiz konkurentsii v rossiiskom banke. Moskva, IEPP: 130.

Mamonov, M. E. (2010). Modelirovaniie konkurentsii v rossiiskom bankovskom sektore s ispolzovaniem podhoda Panzara-Rossa: teoreticheskii i prikladnoi aspect. Bankovskoie delo, 11: 17-24.

Barth, J., G. Caprio, and R. Levine (2000). "Banking systems around the world: Do regulation and ownership affect performance and stability?”Policy Research Working Paper, Cambridge, MA: National Bureau of Economic Research Press.

Shaffer, S. (1998). The winner's curse in banking. Journal of Financial Intermediation, 7 (4): 359-392.

Leonov, S. V. (2009). Invesytsiinyi potentsial bankivskoi systemy Ukrainy, Sumy, UAB NBU: 375.

Hirna, O. Y. (2014). Opysovi ta modelni otsinky bankivskoho rynku Yevropeiskoho Soiuzu ta Ukrainy. Finansovyi prostir, 4 (16).

Moiseev, S. R. (2007). Realii monopolisticheskoi konkurentsii v rossiiskom bankovskom sektore. Sovremennaia konkurentsiia, 1 (1).

Goddard J., Molyneux P. and Wilson J. (2001). European Banking: Efficiency, Technology and Growth. London: John Wiley and Sons.

Bain, J. (1951). Relation of Profit Rate to Industry Concentration. Quarterly Journal of Economics, 65: 293-324.

Demsetz, H. (1973). Information and efficiency: Another viewpoint. Journal of Law and Economics, 10: 1-22.

Barros, F. (1999). Portuguese banking sector: a mixed oligopoly? International Journal of Industrial Organization, 17: 72-86.

Bresnahan, T. F. (1982). The Oligopoly Solution Concept is Identified. Economic Letters, 10: 87-92.

Iwata, G.(1974). Measurment of Conjectural Variations in Oligopoly. Econimetrica, 42: 947-966.

Lau, L. (1982). On Identified the Degree of Competition from Industry Price and Output Data. Economics Letters, 10: 87-92.

Panzar, J. C., Rosse, J. (1987). Testing for Monopoly Equilibrium. Journal of Industrial Economics, 25: $443-456$.

Reforma finansovoho sektoru. Natsionalna Rada reform [Electronic resource]. - Retrieved from: http://reforms.in.ua/ua/reforms/reforma-finansovogo-sektoru.

Bikker, J. A., Spierdijk, L., Finnie P. (2007). Misspecification of the PanzarRosse Model: Assessing Competition in the Banking Industry. DNB Working Papers, 114: 30.

Dani finansovoi zvitnosti bankiv Ukrainy [Electronic resource]. - Retrieved from: http://www.bank.gov.ua/ control/uk/publish/category?cat_id=64097. 


\section{Ирина ДИДЕНКО, Сергей БОГМА}

ИССЛЕДОВАНИЕ КОНКУРЕНЦИИ НА ДЕПОЗИТНОМ РЫНКЕ УКРАИНЫ НА ОСНОВЕ МОДЕЛИ ПАНЗАРА-РОССА

Аннотация. Проблема в адекватной оценке уровня конкуренции на рынке банковских услуг побудила исследователей постоянно искать какие-то новые научные методы. Самыми известными из них на сегодня, которые впоследствии были успешно адаптированы на банковском рынке, являются модели Бреснахана, Панзара-Росса, Бертрана, Ивата, Монти-Кляйна, Барроса-Модесто и др. В Украине процесс оценки уровня конкуренции в банковском секторе является очень актуальной темой, особенно в соответствии с последними реформами в данном направлении. Что касается внутреннего рынка депозитов, существует дефицит качественного анализа этого вопроса, в отличие от зарубежной практики. Поэтому в данном исследовании мы пытаемся решить эту проблему. Основная цель мировых ученых в данном вопросе является подробный анализ рынка, чтобы выявить важные факторы, которые существуют на выделенных рынках, и влияют в частности на ставки по кредитам и депозитам. Исходя из этих факторов, не может быть реализованы процессы внутренней перестройки, происходящие на рынках. Целью данной статьи является определение уровня конкуренции на депозитном рынке Украины в 2006-2015 гг базированной на неструктурной модели Панзара-Росса и определение ключевых факторов, которые влияют на этот уровень. Для исследования уровня конкуренции на депозитном рынке Украины была использована модель ПанзараРосса, В которой с помощью встроенного инструмента «Множественная регрессия» в пакете программного обеспечения для анализа статистики STATISTICA были построены отдельные 11 моделей. В качестве входных данных в модели была представлена информация о результатах финансовой деятельности украинских банков в течение десяти лет с 01.01.2005 года до 01.01.2015 года. Результаты исследования показали, что на украинском рынке депозитов есть монополистическая конкуренция, что подтверждается расчетными значениями индекса Н-статистики. 2008 год, в контексте глобального экономического кризиса, был отмечен как неуравновешенный период для рынка депозитов Украины. Зная текущее состояние уровня конкуренции на рынке, можно объяснить ряд явлений, которые происходят на нем и при этом может быть разработано целый ряд эффективных мер по контролю за ними. В Украине процесс оценки конкуренции в банковском секторе, в соответствии с последними реформами, становится все более популярным и актуальным. Что касается внутреннего рынка депозитов, как уже говорилось, сегодня существует дефицит качественного анализа этого вопроса, в отличие от зарубежной практики. Таким образом, это исследование поможет решить данную проблему. 